\title{
RIKTIG MEDISINBRUK I SYKEHJEM
}

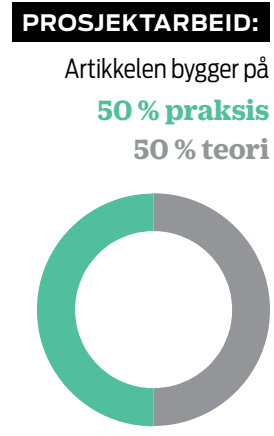

DOI-NUMMER:

10.4220/Sykepleiens.2015.55303

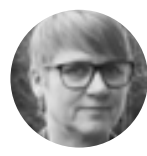

Anne

Marit Græe, Farmasøyt,Cand pharm. Sykehusapoteket Lørenskog



interen 2010-2011 gjennomførte Sykehusapoteket Lørenskog og Skedsmo kommune et prosjekt med legemiddelgjennomganger på to sykehjemsavdelinger i Skedsmo.

TRE FUNN. Første hovedfunn i prosjektet er at sykehjemsbeboerne på disse avdelingene i stor grad behandles i tråd med faglige retningslinjer. Dette kom fram ved at det var lite bruk av legemidler som er uegnet til eldre, jamfør lister som NorGeP og STOPP. Dette er sannsynligvis et resultat av at sykehjemslegene har hatt oppmerksomhet på riktig legemiddelbehandling over tid.

Andre hovedfunn var at ikke alle aktuelle diagnoser var ført i elektronisk journal (Gerica). Det har betydning som dokumentasjon for om legemidler skal brukes videre eller ikke.

Tredje hovedfunn var at legemiddeloversikten ikke alltid samsvarte med det beboerne faktisk fikk av legemidler.

LANGE LISTER. Sykehjemsbeboere har ofte stort hjelpebehov og flere sykdommer. De har gjerne i løpet av et langt liv forholdt seg til flere leger. Begge deler bidrar til lange legemiddellister. En undersøkelse om legemiddelbruk ved to sykehjemsavdelinger i Oslo viste at beboerne brukte fra seks til tolv faste legemidler inkludert vitaminer og kosttilskudd, medianverdi åtte faste legemidler (1).

Lange legemiddellister øker sjansene for legemiddelrelaterte problemer. Dette er definert som en hendelse eller et forhold som skjer i forbindelse med legemiddelbehandling, og som reelt eller potensielt interfererer med ønsket helseeffekt (2). Et legemiddelrelatert problem kan være problemer knyttet til for høy dose, for lav dose, unødvendig legemiddel, manglende legemiddel, interaksjoner, bivirkninger, avvikende legemiddelbruk eller annet. Ved systematisk legemiddelgjennomgang for 224 sykehjemsbeboere i Bergen, der farmasøyt deltok i tverrfaglig team, fant man i snitt 1,98 LRP per beboer (3).

\section{ELEKTRONISKE MELDINGER.}

Ved overgang til elektronisk journal blir den gamle håndskrevne medisinkardexen for legemiddeloversikter borte. Legemiddeloversikter i medikamentmodul i elektronisk journalsystem overtar. Sykehjems legene forholder seg til elektronisk versjon, og det er sykehjemslegene som faktisk fører endringer legemiddeloversikten.

Etter hvert foregår kommunikasjon mellom ulike nivåer i helsetjenesten via Helsenett i form av elektroniske meldinger. Den som sender informasjon, kan hente denne direkte fra eget journalsystem. Da må informasjon i elektronisk journalsystem være korrekt.

PRAKTISK GJENNOMFØRING. Prosjektet ble gjennomført ved at farmasøyten deltok i tverrfaglig team for legemiddelgjennomganger på to sykehjemsavdelinger i Skedsmo. Praktisk gjennomføring bygget på en modell utviklet i Halland i Sverige (4). Farmasøyten gjennomførte undervisning om eldre og legemidler i flere omganger både på dagtid og kveld, slik at flest mulig av de ansatte i avdelingene fikk anledning til å delta.

For å kunne evaluere om endring i legemiddelbehandlingen også medførte endring i atferd, ble det gjennomført en atferdsregistrering av beboerne over en 14-dagers periode både før oppstart og ved avslutning av prosjektet. Skjemaer som allerede var i bruk ved avdelingene tilsvarte de som ble brukt ved Kroken sykehjem i Tromsø (5). Variabler som ble registrert var søvn, våken, uro, smerte og uvel eller svimmelhet.

LEGEMIDDELGJENNOMGANG. Farmasøyten hadde tilgang til legemiddeloversikter og diagnoser fra Gerica, eventuelle laboratoriesvar og signeringslister for gitt lege-
Fakta $\bullet$

Hovedbudlskap

Feil i legemiddeloversikt kan få store konsekvenser for pasienten. Samstemming mågjennomføres for å få korrekt liste over pasientens legemidler i bruk (LIB), også ved elektronisk legemiddeloversikt.

\section{Nøkkelord}

Les mer og finn litteraturhenvisninger på våre nettsider

- Legemidler

- Informasjons-

teknologi

- Dokumentasjon

- Sykehjem 
middel ved forberedelse til møte i tverrfaglig team. Lister over legemidler som er uegnet til eldre som NorGeP (6) og STOPP (7), samt liste over aktuell behandling i forhold til diagnoser, START (7), ble brukt i forberedelsene.

Det viste seg å være vanskelig å få med ansatt med primæransvar for aktuell beboer i de tverrfaglige møtene. Det var derfor lege, sykepleier og farmasøyt som deltok på møtene der potensielle legemiddelrelaterte problemer tatt opp. Ved legemiddelgjennomgangene ble det sett på både faste og eventuelle legemidler. Det ble gjennomført nytt møte med oppfølging etter en måned og på nytt etter fem til seks måneder.

Legemiddelgjennomgangene viste at det var lite bruk av legemidler som etter NorGeP og STOPP er uegnet til eldre. Det var bare en beboer som brukte trisyklisk antidepresivum og en som brukte langtidsvirkende benzodiazepin. Dette viser at legemiddelbehandlingen av beboerne ved de aktuelle sykehjemsavdelingene er i tråd med gjeldende faglige normer.

ETIKK. Det var dialog med Regional etisk komité (REK) før oppstart av prosjektet. REK besluttet at søknad ikke var påkrevd fordi prosjektet var intern kvalitetssikring av legemiddelbehandling for beboerne. Det ble utarbeidet samtykkeskjema som sykepleier gikk gjennom med beboerne.

\section{«Sykehjems- beboere har ofte stort hjelpebehov og flere sykdommer.»}

POTENSIELL PROBLEMER. Faste legemidler kunne ikke alltid knyttes til diagnose i diagnoseoversikt. Der det reelt ikke forelå diagnose, kunne legemidler seponeres. For legemidler som Risperdal tabletter, SeloZok depottabletter, Simvastatin tabletter og Gabapentin tabletter der det forelå diagnoser, ble diagnoser ført i diagnoseoversikt.

En del eventuelle legemidler var ordinert for lang tid siden og diagnoser var ikke lenger aktuelle. Dokumentasjon viste at legemidlene ikke ble gitt. Vival tabletter, OxyNorm tabletter og Veracard tabletter ble avsluttet.

EFFEKT. Salver og kremer brukes ofte en periode eller man prøver om de har effekt. Hvis ønsket effekt uteblir, avsluttes behandlingen. Signeringslister viste at flere legemidler som var ordinert, ikke ble gitt lenger. De skulle vært avsluttet.
Dette var andre legemiddelformer enn tabletter eller kapsler, for eksempel Hydrokortison krem, Zon gel, Differin gel og Canesten krem.

Signeringslister viste at Ovesterin vagitorier som var ordinert og skulle gis, ikke ble gitt. Videre viste signeringslister at enkelte legemidler ble gitt fast uten at de sto på legemiddeloversikt. Typisk her var avføringsmidler som Dulcolax stikkpiller.

KONSEKVENSER. Sett opp mot legemiddelbehandling brukes diagnoser i Gerica for å vurdere om behandlingen er korrekt. Det betyr en vurdering av om diagnoser behandles i samsvar med behandlingsretningslinjer og om det er behov for alle legemidlene.

Med fast sykehjemslege og sykepleiere ved avdelingene, vil noen huske hvorfor et legemiddel er ordinert.




Det er høyst usikkert kunnskap om diagnoser overføres til nye leger og sykepleiere når de ikke er ført i Gerica. Informasjon om diagnoser vil ikke overføres til annet behandlingsnivå via PLO-meldinger når den ikke foreligger i Gerica. Både ny lege og annet behandlingsnivå kan seponere legemidler som skal brukes. For beboeren kan det medføre at nødvendig behandling avsluttes.

NYE TILSTANDER. Eventuelle legemidler som blir stående på legemiddeloversikt etter at indikasjon for bruk ikke er aktuell lenger, kan bli gitt ved behov for nyoppståtte tilstander uten at lege blir kontaktet. Det kan ta lang tid før lege blir informert om beboers tilstand og om bruk av eventuelle legemidler. Det er ikke sikkert legemiddelet er det riktige for den nyoppståtte tilstanden.

MANGLENDE INFORMASJON. Full informasjon om hvilke legemidler som gis, inkludert avføringsmidler, er nødvendig for å vurdere legemiddelbehandlingen. Manglende informasjon kan medføre at lege velger en behandling som er uegnet for beboeren. For eksempel bør ikke kalsiumantagonister velges hvis beboer i utgangspunktet har store problemer med forstoppelse (STOPP-listen).

BRUDD PÅ FORSKRIFT. Når legemidler gis til sykehjemsbeboere uten at de er ordinert av lege, er det i tillegg et brudd på forskrift om legemiddelhåndtering. Ifølge $\S 7 \mathrm{i}$ forskriften skal grunnlaget for istandgjøring og utdeling være ordinasjon gjort av lege (eller andre med rekvisisjonsrett). Det gjelder alle legemidler, både reseptpliktige eller reseptfrie. Legemidler som gis fast uten at de er oppført på legemiddeloversikt, kan ikke sies å være ordinert av lege.

FEIL GRUNNLAG. Sykehjemslegen går ut fra at ordinerte legemidler gis og vurderer behandling ut fra dette. Når dette ikke stemmer, blir grunnlaget for vurderinger feil. Med korrekt informasjon om hvilke legemidler som gis, kan vurderinger bli annerledes i forhold til behandling. Hvis en profylaktisk behandling ikke gis, er det aktuelt å vurdere annen profylakse.

Når man ikke seponerer salve eller krem som viste seg ikke å gi ønsket effekt, kan ansatte som ikke er godt kjent med beboer komme til å gi et legemiddel som ikke skal brukes. Eller de bruker unødig tid på å finne ut om ordinert legemiddel skal gis.

ANDRE KONSEKVENSER. Med elektroniske meldinger ved skifte av omsorgsnivå, kan opplysninger som skal videreformidles, som legemiddeloversikter, hentes direkte fra Gerica. Det er en rask og enkel måte å sikre overføring av riktige opplysninger på. Dette skal være tidsbesparende for begge parter.

Når legemiddeloversikten inneholder legemidler som ikke gis, eller når man gir legemidler fast som ikke er oppført, får mottaker feil opplysninger. Det kan få konsekvenser for beboers behandling på neste omsorgsnivå. Legemiddelbehandlingen kan bli feil, eller ansatte bruker unødig tid på å inn hente riktige opplysninger. Da får man ikke de positive forbedringer PLO-meldinger skulle gi med å forhindre feil knyttet til informasjonsoverføring og unødig tidsbruk.

AVVIK. Ved bruk av den gamle, håndskrevne medisinkardexen, var det kun den man forholdt seg til. Sykepleier kunne stryke med markørpenn over legemidler som ikke lenger skulle gis. Ved oppstart av behandling på dager der lege ikke var til stede, førte sykepleier etter avtale legemiddel i kardex. Lege signerte endringene ved første visitt. Med elektronisk medisinoversikt brukes i praksis både den elektroniske i journalsystemet og papirutskrift av denne. Endringer gjøres elektronisk av lege som tar ny utskrift. Det krever tett samarbeid mellom sykepleiere og lege om avslutning eller ordinering i elektronisk oversikt. Dette kan glippe i en travel hverdag. Da vil ordinasjon være opprettholdt eller mangle i den elektroniske medisinoversikten.

Ved de aktuelle avdelinger hadde de signeringslister der man dokumenterte at multidose eller dosett var gitt. I tillegg var alle legemidler utenom multidose eller dosett oppført slik at man fikk dokumentert at hvert enkelt av dem var gitt. Ved utdeling forholdt man seg til utskrift fra medisinoversikt og signeringsliste. Hvis endringer ikke var tatt opp med lege, kunne liste-

«Lange ne avvike fra elektro-

\section{legemiddellister øker sjansene for legemiddel- relaterte problemer.»} nisk oversikt.

KONKLUSJON. Regelmessig systematisk gjennomgang av beboeres legemiddelbruk vil sikre at lister samsvarer med det beboere faktisk får. Pasientsikkerhetskampanjen med innsatsområdene «Samstemming" og "Riktig legemiddelbruk på sykehjem» er bidrag til dette. Der legges det opp til å bruke sjekkliste for systematisk legemiddelgjennomgang. Funnene i denne studien tyder på at slik systematisk samstemming og legemiddelgjennomgang må gjennomføres rutinemessig for å øke pasientsikkerheten ved legemiddelbruk.

Prosjektet mottok økonomisk støtte fra Helsedirektoratet.


turerad arbetsmetod för gjenomgång av äldres läkemedel. Lækartidningen nr. 11 2011 volum 108: 606-8.

5. Riksvold, E Legemiddelgjennomgang i sykehjem og hjemmetjenesten i Troms $ø$ kommune. Norsk Farmaceutisk Tidsskrift 2012;6: 12-13.

6. Rognstad S, Brekke M, Fetveit A et al The Norwegian General Practice (NorGeP) criteria for assessing ptentially inapropriate prescriptions to elderly patients. Scand J Prim Health Care 2009; 27: 153-9.

7. Bakken MS, Granås AG, Ruths $S$ et al Oversatt versjon av: Gallagher P, Ryan C, Byrne S et al STOPP (screening Tool og Older persons 'Prescriptions) and START (Screening Tool to Alert Doctors to Right Tratment) consensus validation Int J Clin Pharm Ther 2008:46: 71-83. Norsk verion 2010 Oppdatet nork vesjon 2014 tigjenger

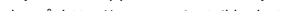
.eks. på: http://www.pasientsikkerhetsprogrammet.no/ no/I+trygge+hender/Innsatsomr\%C3\%A5der/_attachment/3204?_ts=14c0824d46e.

FAGARTIKLER

Fagartikler kan sendes ti torhild.apall@ sykepleien.no 